\title{
Review
}

\section{Upper Gastrointestinal Cancer Surveillance in Lynch Syndrome}

\author{
Shria Kumar ${ }^{1}$, Natalie Farha ${ }^{2}$, Carol A. Burke ${ }^{3}$ and Bryson W. Katona ${ }^{4, *}$ (D) \\ 1 Division of Digestive Health and Liver Diseases, University of Miami Miller School of Medicine, \\ Miami, FL 33136, USA; shriakumar@med.miami.edu \\ 2 Department of Internal Medicine, Cleveland Clinic, Cleveland, OH 44195, USA; farhan@ccf.org \\ 3 Department of Gastroenterology, Hepatology \& Nutrition, Cleveland Clinic, Cleveland, OH 44195, USA; \\ burkec1@ccf.org \\ 4 Division of Gastroenterology and Hepatology, Perelman School of Medicine, University of Pennsylvania, \\ Philadelphia, PA 19104, USA \\ * Correspondence: bryson.katona@pennmedicine.upenn.edu; Tel.: +1-215-349-8222; Fax: +1-215-349-5915
}

check for updates

Citation: Kumar, S.; Farha, N.; Burke, C.A.; Katona, B.W. Upper Gastrointestinal Cancer Surveillance in Lynch Syndrome. Cancers 2022, 14, 1000. https://doi.org/10.3390/ cancers 14041000

Academic Editor: Gianluca Masi

Received: 28 December 2021

Accepted: 9 February 2022

Published: 16 February 2022

Publisher's Note: MDPI stays neutral with regard to jurisdictional claims in published maps and institutional affiliations.

Copyright: (C) 2022 by the authors. Licensee MDPI, Basel, Switzerland. This article is an open access article distributed under the terms and conditions of the Creative Commons Attribution (CC BY) license (https:// creativecommons.org/licenses/by/ $4.0 /)$.
Simple Summary: Lynch syndrome is the most common cause of hereditary colorectal cancer, but is also associated with increased extracolonic cancer risk, including upper gastrointestinal cancers. While there is agreement regarding the benefit of frequent colonoscopic surveillance in Lynch syndrome, there remains a lack of consensus on the use of upper gastrointestinal cancer surveillance. Here, we review the upper gastrointestinal cancer risks in Lynch syndrome, the varying guideline recommendations in this area, and the published outcomes of upper gastrointestinal cancer surveillance in this high-risk population. Finally, we highlight ongoing controversies in upper gastrointestinal cancer surveillance and opine on how upper gastrointestinal cancer surveillance can be incorporated into a Lynch syndrome risk management program. Upper gastrointestinal cancer surveillance is an increasingly studied area of risk management in Lynch syndrome, and continued research will be vital in determining how to best incorporate this surveillance in these high-risk patients.

\begin{abstract}
Lynch syndrome is a common hereditary cancer predisposition syndrome associated with increased digestive cancer risk including colorectal, gastric, and duodenal cancers. While colorectal cancer surveillance is widely accepted to be an important part of a comprehensive Lynch syndrome risk management plan, the use of upper gastrointestinal cancer surveillance in Lynch syndrome remains more controversial. Currently, upper gastrointestinal cancer surveillance guidelines for Lynch syndrome vary widely, and there is no consensus on who should undergo upper gastrointestinal cancer surveillance, how surveillance should be performed, the age at which to initiate surveillance, or how often individuals with Lynch syndrome should undergo upper gastrointestinal cancer surveillance. Fortunately, research groups around the world have been focusing on upper gastrointestinal cancer surveillance in Lynch syndrome, and recent evidence in this field has demonstrated that upper gastrointestinal cancer surveillance can be performed with identification of precancerous lesions as well as early-stage upper gastrointestinal cancers. In this manuscript, we review the upper gastrointestinal cancer risks in Lynch syndrome, differing guideline recommendations for surveillance, outcomes of upper gastrointestinal cancer surveillance, and controversies in the field, and we provide a framework based on our collective experience with which to incorporate upper gastrointestinal cancer surveillance into a risk management program for individuals with Lynch syndrome.
\end{abstract}

Keywords: Lynch syndrome; upper gastrointestinal cancer; surveillance; upper endoscopy

\section{Introduction}

Lynch syndrome is among the most common hereditary cancer predisposition syndromes, leading to a substantially increased risk of colorectal cancer (CRC) [1]. The risk for extra-colonic cancers is also increased, including endometrial and ovarian cancers, as well as gastric, biliary, urinary tract, pancreatic, skin, and small bowel cancers [2]. Lynch 
syndrome results from germline pathogenic variants in genes involved in the DNA mismatch repair pathway including $M L H 1, M S H 2, M S H 6, P M S 2$ as well as EPCAM, whose deletion leads to hypermethylation and silencing of $M S H 2$ [2-4]. Given the role of Lynch syndrome-related genes in mismatch repair, Lynch syndrome-associated tumors classically exhibit mismatch repair deficiency associated with microsatellite instability and increased tumor mutational burden [2-5].

The lifetime cancer risk for some patients affected with Lynch syndrome can be over $50 \%$ for colorectal and endometrial cancer [6]. There is consensus among guidelines recommending aggressive colorectal surveillance to improve mortality from CRC, as well as prophylactic hysterectomy to reduce endometrial cancer risk $[7,8]$. The role for surveillance of other Lynch syndrome-related cancers with lower, but still substantially elevated, risk compared to the general population remains an area of persistent uncertainty. This is particularly true for cancers of the upper gastrointestinal (UGI) tract. While the general population has a lifetime risk of $0.9 \%$ and $0.3 \%$ for gastric cancer and duodenal cancer, respectively, in Lynch syndrome, this risk can be as high as 9\% and 11\%, respectively [7,9-12]. However, there are marked variations of cancer risk by age and by gene. For example, the Prospective Lynch Syndrome Database demonstrated marked differences in UGI cancer risk by age and pathogenic variant, with UGI cancers occurring less frequently among younger age groups [13]. Numerous guidelines both within and outside the United States address UGI surveillance in Lynch syndrome, but there remains a lack of consensus regarding the efficacy of UGI surveillance and the surveillance approach (Table 1). When UGI surveillance is performed in Lynch syndrome, it is typically carried out with upper endoscopy or esophagogastroduodenoscopy (EGD), which is a diagnostic endoscopic procedure that visualizes the UGI tract. In addition to inspection, biopsies obtained during upper endoscopy can evaluate for Helicobacter pylori infection and precancerous lesions, such as atrophic gastritis, intestinal metaplasia, and dysplasia. Similar to colonoscopy, upper endoscopy can be repeated at regular intervals to surveil for cancers, including those in the esophagus, stomach, and duodenum.

The multitude of guidelines addressing UGI surveillance in Lynch syndrome are not uniform and vary in multiple aspects (Table 1). While some guidelines do not recommend routine surveillance and instead recommend only evaluating for Helicobacter pylori infection [14], newer guidelines often recommend surveillance of higher risk groups, yet the definition of a high-risk group is not consistent [7,15-17]. The recommended age of initiation of UGI surveillance also varies greatly, with some guidelines not proposing a specific age to initiate surveillance $[15,16]$, while others recommend initiation at different times between ages 30-40 years [7,17-19]. Lastly, the suggested surveillance interval is also inconsistent, with recommended intervals ranging between every 1 to 5 years depending on the particular guideline [7,15-19].

The lack of consensus regarding support of UGI surveillance in Lynch syndrome is related to the lack of evidence supporting its utility. However, over the last several years there have been a plethora of studies providing important data highlighting the role of UGI surveillance in Lynch syndrome, strengthening the evidence supporting its regular use as part of a comprehensive risk-management program for Lynch syndrome. Herein, we review the literature regarding UGI cancer risk and outcomes of endoscopic surveillance of UGI cancers in Lynch syndrome, describing areas of controversy, and offering our own perspectives on how to effectively incorporate UGI surveillance into the care of patients with Lynch syndrome. 
Table 1. Summary of current guidelines addressing UGI cancer surveillance in Lynch syndrome.

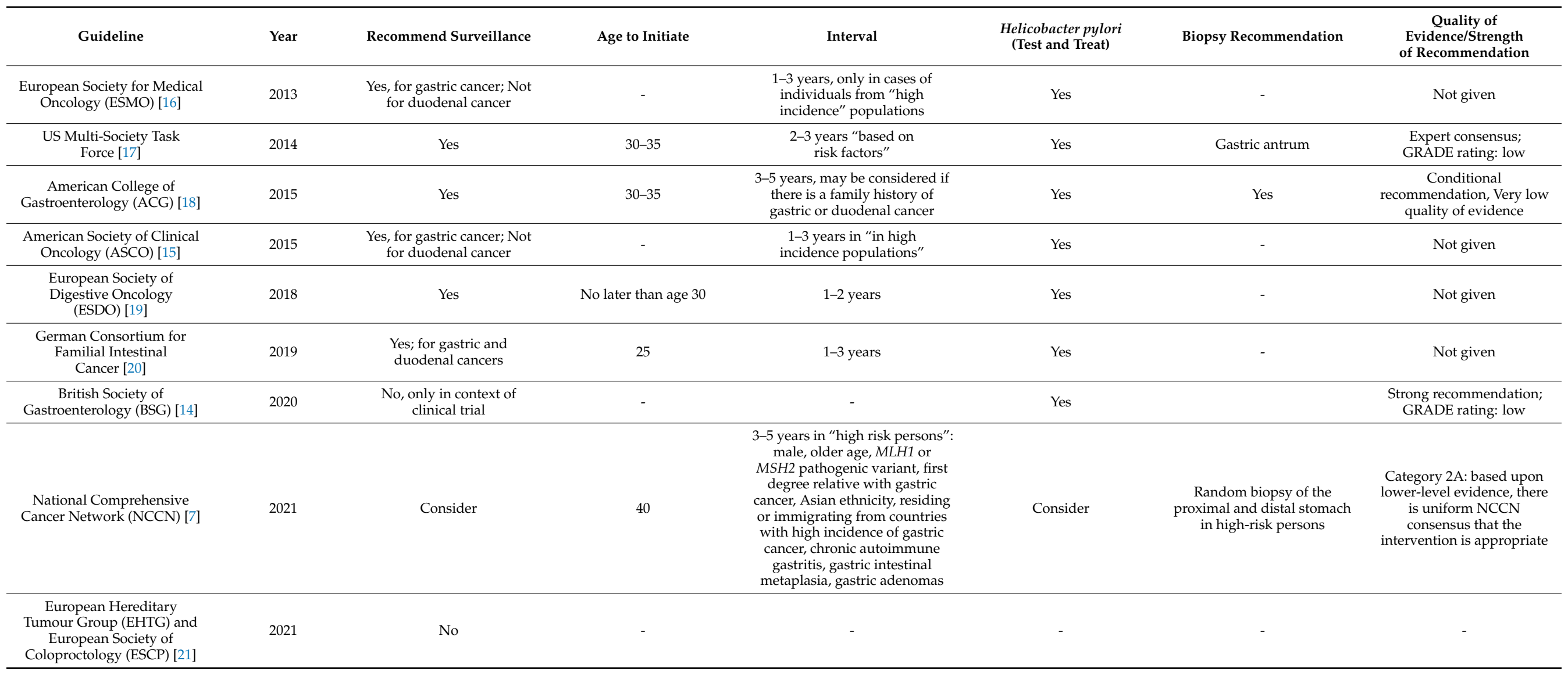




\section{Esophageal Cancer}

Esophageal cancer is not classically considered a Lynch syndrome-associated malignancy. Classical risk factors for esophageal adenocarcinoma include male sex, increasing age, obesity, chronic acid reflux, and Barrett's esophagus [22]. While the incidence of esophageal adenocarcinoma is increasing in western countries [23,24], worldwide, squamous cell cancer remains the more common esophageal cancer and is associated with smoking and alcohol intake [22]. These risk factors can co-exist in individuals with Lynch syndrome, and may predispose these patients to esophageal cancer, despite esophageal cancer being outside of the classic spectrum of Lynch syndrome-associated UGI cancers.

Endoscopy can detect esophageal cancer, even those at an early stage [25]. Using a combination of high-definition white light, narrow band imaging, and both targeted and random biopsy, endoscopy can detect mucosal abnormalities that indicate preneoplastic or neoplastic conditions of the esophagus [26-29]. These findings can include nodularity, altered pit pattern or vascularity, depression, and protruding lesions, with upper endoscopy being recommended for esophageal cancer surveillance for individuals at high risk [30]. Accordingly, there are guidelines for screening of esophageal cancer in those at high risk, which in western countries focus primarily on surveilling for lesions associated with Barrett's esophagus [26-29].

Unlike gastric and duodenal findings, there is a paucity of data about esophageal findings in patients with Lynch syndrome. A recent study of 323 individuals with Lynch syndrome undergoing EGD surveillance identified 6.5\% with Barrett's esophagus; of those with Barrett's esophagus, $9.5 \%$ had dysplasia and 1 patient ( $0.3 \%$ of the overall cohort) had Barrett's esophagus-related esophageal adenocarcinoma [31]. In this study, the relatively frequent finding of Barrett's esophagus was twice the prevalence reported by the only other study of EGD surveillance in Lynch syndrome to report Barrett's esophagus, in which of 217 patients, 7 (3.2\%) were identified to have Barrett's esophagus, with only 1 of these 7 patients having dysplasia (authors' own unpublished data) [32]. The prevalence of Barrett's esophagus in the general population is unknown-with estimates from clinical and modeling studies ranging from $\sim 1 \%$ to above $6 \%$ [33-35]. With uncertain estimates within Lynch syndrome, it is unclear if Lynch syndrome portends a higher risk of Barrett's esophagus than the general population.

Mismatch repair-deficient esophageal adenocarcinomas have also been identified in Lynch syndrome. A recent report identified a stage I esophageal adenocarcinoma in a 56-year old female MSH2 carrier with known Barrett's esophagus who was undergoing endoscopic surveillance [31,36]. Additionally, two case reports including one of an 84-year old woman and the other a 35-year old man, both with MSH2-associated Lynch syndrome, described esophageal adenocarcinoma, both lacking expression of $\mathrm{MSH} 2$ on immunohistochemistry (IHC) [37,38]. Among these two lesions, one was in a pedunculated polyp, while the other was in a cervical inlet patch. The cervical inlet patch, with underlying heterotopic gastric mucosa, is a common and typically incidental finding with minimal, if any, clinical relevance [39]. The risk of adenocarcinoma arising from heterotopic gastric mucosa is thought to be low [39,40], but cervical inlet patches should be carefully examined in all individuals undergoing upper endoscopy. While these reported cases of esophageal adenocarcinoma in Lynch syndrome were mismatch repair deficient, the majority of mismatch-deficient esophageal adenocarcinomas are not related to Lynch syndrome, and $3-5 \%$ of esophageal adenocarcinomas have been found to harbor somatic mismatch repair deficiency [41,42].

In summary, esophageal cancer is not recognized as a classic Lynch syndrome-associated malignancy. However, given that upper endoscopy can detect esophageal cancer and its precursor lesions, endoscopic surveillance for UGI malignancies in Lynch syndrome may also detect esophageal neoplasia. For example, in a series of individuals with Lynch syndrome patients undergoing UGI surveillance, an esophageal squamous cell cancer was identified, highlighting the importance of careful endoscopic examination of the esophagus in Lynch syndrome, even for non-classical neoplastic associations [32]. 


\section{Gastric Cancer}

Individuals with Lynch syndrome are at increased risk of gastric cancer [1,43]. Gastric cancer risk varies by pathogenic variant with $M L H 1$ and $M S H 2$ carriers having a higher risk compared to MSH6 and PMS2 carriers [44]. A recent summary from the National Comprehensive Cancer Network (NCCN) highlights the range of gene-specific gastric cancer risk in Lynch syndrome (Table 2) [7]. This summary demonstrated lifetime risk was $5-7 \%$ for $M L H 1$ carriers, $0.2-9 \%$ for $M S H 2$ and EPCAM carriers, and $<1-7.9 \%$ in $M S H 6$ carriers, and importantly notes that the risk for PMS2 carriers is unknown, illustrating the uncertainty of whether gastric cancer risk is increased for PMS2 carriers.

Table 2. Lifetime risk of gastric and small bowel cancers in Lynch syndrome by pathogenic variant [7,9-12].

\begin{tabular}{|c|c|c|}
\hline Pathogenic Variant & Affected Individuals, Lifetime Risk & General Population, Lifetime Risk \\
\hline \multicolumn{3}{|l|}{ Gastric Cancer } \\
\hline MLH1 & $5-7 \%$ & $0.9 \%$ \\
\hline MSH2and EPCAM & $0.2-9 \%$ & \\
\hline MSH6 & $\leq 1-7.9 \%$ & \\
\hline PMS2 & Inadequate data & \\
\hline \multicolumn{3}{|l|}{ Small Bowel Cancer } \\
\hline MLH1 & $0.4-11 \%$ & $0.3 \%$ \\
\hline MSH2and EPCAM & $1.1-10 \%$ & \\
\hline MSH6 & $\leq 1-4 \%$ & \\
\hline PMS2 & $0.1-0.3 \%$ & \\
\hline
\end{tabular}

Multiple guidelines recommend surveillance based on patient-specific risk factors. While risk factors for Lynch syndrome-related gastric cancers have been identified and include male sex, increasing age, and family history of gastric cancer [44], gastric cancer has also been diagnosed among patients without these risk factors [32,45-47]. Furthermore, guidelines are not consistent in their definition of who is considered a high-risk individual. For example, the NCCN recognizes risk factors that include male sex, older age, $M L H 1$ or MSH2 pathogenic variant, first-degree relative with gastric cancer, Asian ethnicity, residing or immigrating from countries with high incidence of gastric cancer, and a history of chronic autoimmune gastritis, gastric intestinal metaplasia, or gastric adenomas [7], but the American College of Gastroenterology (ACG) recommends risk stratification based on family history alone [18]. As such, it remains uncertain how to best utilize risk factors to determine which patients with Lynch syndrome should undergo UGI surveillance. It is also likely that UGI surveillance should be dependent on the particular Lynch syndrome gene affected as there are multiple studies demonstrating differential risk by pathogenic variant, including a study among individuals testing positive for Lynch syndrome at a commercial laboratory in the United States [44], the international, multicenter Prospective Lynch Syndrome Database [48], and studies from European cancer registries [49-51].

The endoscopic appearance of gastric cancers in Lynch syndrome has been described by several studies. In a series of 217 patients with Lynch syndrome undergoing upper endoscopic surveillance, gastric cancer was detected as a visible mass or a polyp in six patients $(2.8 \%)$ [32]. In this series, pre-cancerous upper endoscopy findings identified included gastric intestinal metaplasia (18, 8.3\%) and Helicobacter pylori (6, 2.8\%). Gastric neoplasia has been reported in two additional series of UGI Lynch syndrome surveillance. In 323 asymptomatic patients undergoing EGD surveillance, two patients $(0.6 \%)$, both with an $\mathrm{MSH} 2$ pathogenic variant, were found to have gastric cancer-one type 3 gastric neuroendocrine tumor and one gastric adenocarcinoma identified as a solitary ulcerated mass in the proximal stomach [31]. Notably, both gastric cancers were identified at an early stage. In this series, 32 patients $(6 \%)$ had at least one lesion associated with gastric carcinogenesis, including $4 \%$ with Helicobacter pylori, $6 \%$ with gastric intestinal metaplasia, 
$2 \%$ with gastric hyperplastic polyps $>5 \mathrm{~mm}$, and $1 \%$ with gastric adenomas. In another study of 247 asymptomatic patients with either a mismatch repair pathogenic variant or clinical features suggestive of Lynch syndrome undergoing EGD surveillance over a mean of 5.7 years, an average of 3.5 EGDs were conducted at an interval of 2.3 years between exams [45]. Gastric cancer was detected in two patients $(0.8 \%)$, one early stage; antral cancer was detected in the setting of Helicobacter pylori at first EGD in an MSH6 carrier and the other in the cardia at late stage 5 years after a prior EGD in an $M S H 2$ carrier. Pre-cancerous lesions of the stomach and duodenum were described in eight (3.2\%) patients. The gastric findings included gastric foveolar dysplasia, gastric adenomas, and intestinal metaplasia in $10.1 \%$, and chronic gastritis with Helicobacter pylori in $6.9 \%$.

Despite these studies describing gastric cancers in Lynch syndrome, the pathogenesis of gastric cancer in Lynch syndrome remains incompletely understood. In sporadic cases, gastric carcinogenesis proceeds down a defined pathway from chronic gastritis to gastric adenocarcinoma (the "Correa cascade"): chronic gastritis, atrophic gastritis, intestinal metaplasia, dysplasia, then finally, adenocarcinoma [52]. Infection with Helicobacter pylori is thought to be a necessary component of this cascade [53]. While consensus guidelines frequently recommend testing for and eradication of Helicobacter pylori infection, the rates of Helicobacter pylori infection in individuals with Lynch syndrome appear to vary, along with the precancerous lesions associated with sporadic gastric carcinogenesis. Among a cohort of 255 individuals with Lynch syndrome, seven patients (2.7\%) developed gastric cancer, including five with concomitant chronic immune gastritis [54]. On the other hand, the frequency of intestinal metaplasia did not differ between patients who developed cancer versus those who did not and in the overall cohort, Helicobacter pylori infection itself was rare (2.8\%) [32]. Other studies, including one from the Dutch Hereditary Cancer Registry, found that Helicobacter pylori was not associated with increased gastric cancer risk in Lynch syndrome $[49,55]$. A French study also found no association between preceding histologic abnormalities and future gastric cancer risk [47]. Despite this, all published guidelines routinely recommend testing for and eradicating Helicobacter pylori infection-though they do not uniformly recommend biopsies for histological evaluation $[15,16,18,19,56]$. While Helicobacter pylori infection is considered a class I carcinogen and eradication decreases future gastric cancer risk, it is not clear that Helicobacter pylori infection is driving the majority of Lynch-associated gastric cancers [57].

Another intriguing theory about Lynch syndrome-associated gastric carcinogenesis is whether these cancers develop via an accelerated alternative pathway. In Lynch syndromeassociated CRC, there is a well-recognized accelerated adenoma to carcinoma progression, where malignant transformation occurs within a few years, as opposed to 10 or more years in individuals without Lynch syndrome [58]. Accordingly, colonoscopic surveillance for Lynch syndrome is recommended at short intervals $[7,15,17,18]$. While the same pathway is not well-established for gastric carcinogenesis, a 2018 German study of 44 subjects undergoing surveillance noted the possibility of endoscopic surveillance being able to detect and remove adenomas at a precancerous stage, but in this study, adenomas were rare (only five detected adenomas) [59]. However, the ability to detect early-stage gastric cancers by endoscopic surveillance has been better established. In a 2020 study of 217 patients, $80 \%$ of detected cancers were stage I [32]. In a 2021 study of 323 patients, all gastric cancers were detected at early stage [31]. In another 2021 study of 1128 individuals, patients who were found to have gastric cancer while undergoing regular surveillance were diagnosed significantly more often in early-stage disease than those gastric cancers detected through work-up of symptoms $(83 \%$ vs. $25 \%$; $p=0.02)$ [46]. In all of these studies, gastric cancers that developed during surveillance were typically detected within 2 years of a prior surveillance exam, thus further supporting the possibility of an accelerated carcinogenesis pathway in Lynch syndrome-associated gastric cancers. Notably, studies have not uniformly demonstrated a clear survival benefit resulting from UGI endoscopic surveillance, and this, along with assessing the cost-effectiveness of an UGI surveillance program, is an essential next step in the field. 
Finally, gastric neuroendocrine tumors in Lynch syndrome have not been consistently reported; however, a study of 323 patients with Lynch syndrome underdoing endoscopic surveillance did detect one, with loss of $M S H 2$ protein expression [31]. As more UGI surveillance data are collected on Lynch syndrome, this may be an area of further study.

\section{Duodenal Cancer}

Duodenal cancers are rare, occurring in only $0.3 \%$ of the general population $[10,12]$. Individuals with Lynch syndrome are at higher risk of duodenal cancer with a relative risk of 30 to 100 times that of the general population. As with gastric cancer the risk of duodenal cancer is dependent on pathogenic variant (Table 2). While for those with a MLH1 or MSH2 pathogenic variant the lifetime risk of duodenal cancer is as high as $10-11 \%$, the risk for carriers of other pathogenic variants is widely ranging, with suggestion that PMS2 carriers have a risk no higher than the general population $[10,12]$.

Few studies have focused on duodenal cancers in Lynch syndrome; however, similar to other digestive Lynch syndrome-related cancers there have been histologic and molecular findings of microsatellite instability in duodenal cancers $[60,61]$. In a French cohort of 154 individuals with Lynch syndrome undergoing endoscopic evaluation, three duodenal cancers were noted, all in MSH2 carriers [62]. These cancers appeared as flat lesions in the first or second portion of the duodenum. Among three US cohort studies including a total of 825 individuals with Lynch syndrome, eight patients developed duodenal cancer [26,27,39]. Seven were duodenal adenocarcinomas and one was a neuroendocrine tumor. Three of the patients had variants in MSH2, three in MLH1, one in PMS2 and the neuroendocrine tumor was identified in a patient who met revised Bethesda criteria. Current data support that carriers of a $M S H 2$ or $M L H 1$ pathogenic variant have the highest duodenal cancer risk amongst all individuals with Lynch syndrome [50,51]. Whether small bowel neuroendocrine tumors are associated with Lynch syndrome is not established as only a few cases have been reported $[36,45]$. Of the published reports regarding GI neuroendocrine tumors in Lynch syndrome, two have been in the colon [63], one in the rectum [63], and three in the small bowel [64].

A recent German study evaluating the detection of duodenal cancer in Lynch syndrome identified 49 duodenal cancers in 47 patients, with the majority (91\%) of patients having a $M L H 1$ or $M S H 2$ pathogenic variant [65]. While the median age at diagnosis of duodenal cancer was 51.7 years, $10 \%$ of patients were less than 35 years old at the time of diagnosis. Patients under EGD surveillance had earlier-stage (stage I-IIA) detection in 77\% versus $29 \%$ of patients in the non-surveillance group. Duodenal adenomas were reported including one diagnosed synchronous with a duodenal cancer and three detected five, six, and twelve months before a duodenal cancer diagnosis. This study did not report if the adenomas were completely resected as incompletely resected duodenal adenomas may have been the precursor to the duodenal cancers detected. In this study, those in the surveillance group underwent an average of 8.1 upper endoscopies per patient (and 11.3 colonoscopies per patient). Those cancers detected outside surveillance were in patients who underwent 4.9 endoscopies per patient (and 6.8 colonoscopies per patient), suggesting some difference in adherence, but also that surveillance requires more procedures.

The precursors of duodenal cancer in Lynch syndrome are presumed to be duodenal adenomas; however, most studies have not reported a high rate of duodenal adenoma identification. In recent studies from Western populations with Lynch syndrome, duodenal adenomas have been reported in $1.5-2.4 \%$ of the cohorts $[31,32,44,62]$. Whether mismatch repair-deficient crypts may also serve as duodenal adenocarcinoma precursors in Lynch syndrome, similar to colonic mismatch repair deficient crypts, is currently unknown. Additionally, little is known about the risk factors for Lynch syndrome-associated duodenal cancers [66,67]. Future studies should evaluate identifiable risk factors for duodenal neoplasia to better risk stratify patients for surveillance, determine whether surveillance prevents death from duodenal cancers, and assess the cost-effectiveness of UGI surveillance. 


\section{Current Guidelines}

Guidelines vary markedly with recommendations for UGI surveillance in Lynch syndrome. As is evident from Table 1, there is a lack of consensus on: (1) whether or not to perform an initial UGI cancer surveillance exam or follow up surveillance (2) the age to initiate surveillance and (3) the interval to perform surveillance. Helicobacter pylori testing and eradication is universally endorsed; however, universal assessment for premalignant conditions associated with gastric cancer such as atrophic gastritis and intestinal metaplasia remains a point where there is lack of consensus.

\section{UGI Surveillance Implementation and Controversies}

Given the increased risk of UGI cancers in Lynch syndrome and the current data highlighting early-stage detection of UGI cancers in Lynch syndrome (Table 3), we suggest that surveillance for UGI cancers in Lynch syndrome should be a part of a routine Lynch syndrome risk management plan. Furthermore, we would recommend that all individuals with Lynch syndrome who undergo UGI surveillance do so in centers with Lynch syndrome expertise, which will help facilitate prospective data collection on UGI surveillance outcomes.

Based on our collective experience, we would recommend that at the time of Lynch syndrome diagnosis, testing for Helicobacter pylori should be undertaken, with treatment of a positive result and confirmation of Helicobacter pylori eradication (Figure 1). For those under age 30, non-invasive testing can be performed, whereas for those age 30 and older, testing can be performed at the time of surveillance upper endoscopy. We suggest random biopsies from the gastric antrum and body be obtained on the initial upper GI exam, and on subsequent exams based on suspicious visual findings to allow for detection of gastric precursor lesions, which if present may necessitate shorter surveillance intervals. Upper endoscopy should also be performed at the time the individual is undergoing surveillance colonoscopy, rather than as a standalone procedure, which minimizes additional anesthesia and adds little risk or procedure time for patients already undergoing colonoscopy $[7,68,69]$. Additionally, push enteroscopy can be considered instead of routine upper endoscopy to allow for assessment of the complete duodenum and proximal jejunum, though there is no clear data to support this.

It is known that colorectal and gynecologic-related cancers often develop at earlier ages in Lynch syndrome compared to the general population [7,70], and data confirm this in UGI cancers as well $[49,54,65]$. Therefore, we advocate for early initiation of UGI surveillance in Lynch syndrome beginning at age 30, or 2-5 years before the youngest UGI cancer in the family, whichever is earliest (Figure 2). While this surveillance should ideally be performed simultaneously with a surveillance colonoscopy, expeditious diagnostic upper endoscopy is warranted to evaluate concerning UGI signs or symptoms.

The frequency of surveillance remains unknown, yet data from multiple studies suggest consideration of a short UGI surveillance interval [32,44,59]. We recommend a 2-3-year surveillance interval with consideration of shorter surveillance intervals if there are any risk factors, such as family history of UGI cancer, Barrett's esophagus with dysplasia, gastric intestinal metaplasia that is incomplete and/or extensive, or duodenal or gastric adenomas. Random biopsies from the gastric antrum and body should at minimum be obtained on the initial exam to allow for detection of Helicobacter pylori as well as gastric precursor lesions including gastric intestinal metaplasia, which if present may necessitate shorter surveillance intervals (Figure 2).

Of note, data are lacking regarding the association between Helicobacter pylori and gastric cancer in Lynch syndrome, as well as family history; therefore, the above is based on our collective centers' experience. Most data suggest that $M S H 2$ and $M L H 1$ pathogenic variants are associated with an increased risk of UGI cancer, but we believe that at this time there are not enough data available to stratify surveillance based on pathogenic variant alone. As we note above, even patients with "lower risk" Lynch syndrome variants have had UGI cancer and neoplasia detected on surveillance. Furthermore, it is possible with additional 
studies of UGI surveillance in Lynch syndrome that gene-specific recommendations may be appropriate; however, until those data are available, we recommend surveillance among all pathogenic variants.

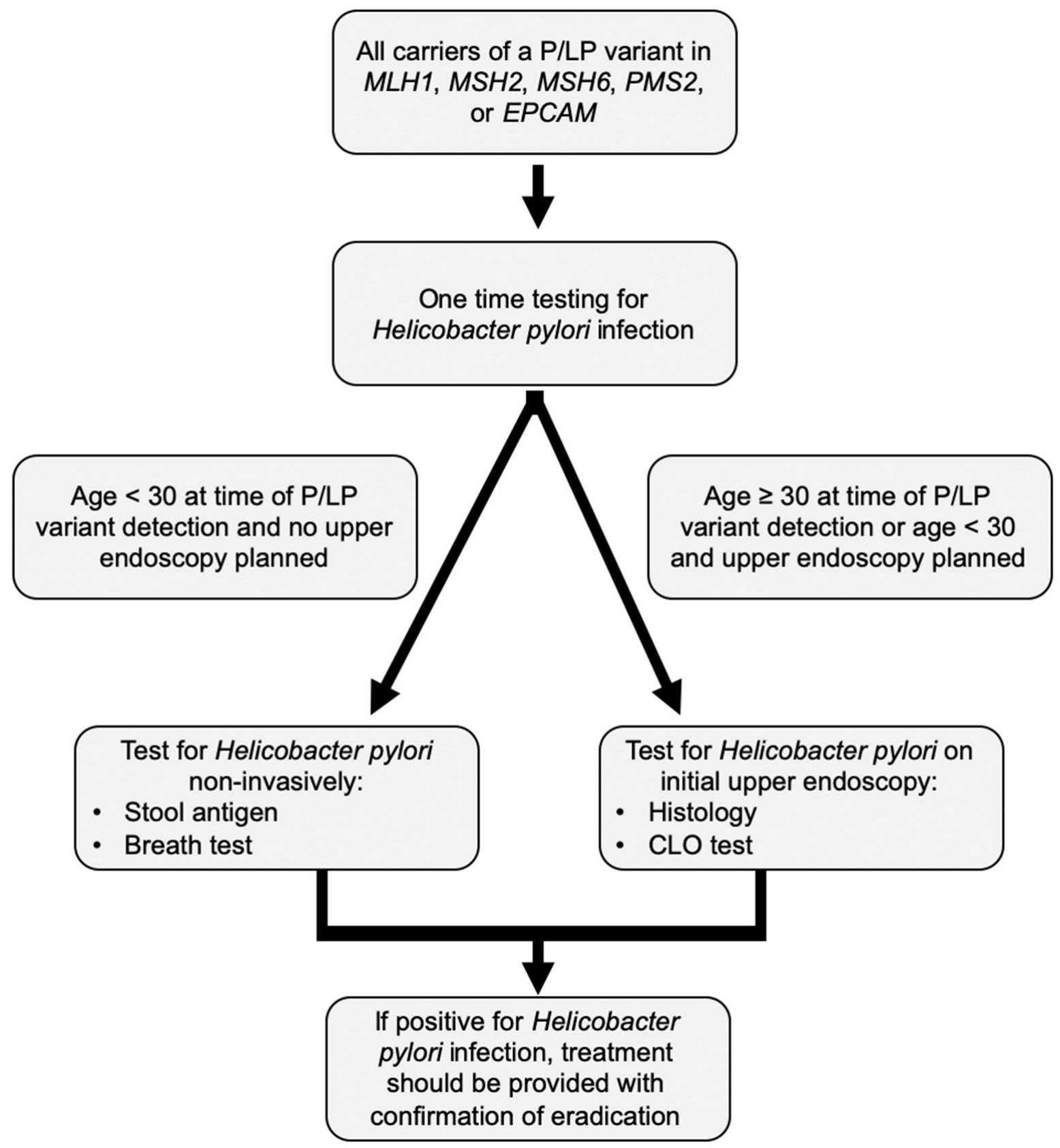

Figure 1. Authors' approach to Helicobacter pylori screening in Lynch syndrome. P/LP variant: Pathogenic/Likely pathogenic variant; CLO test: Campylobacter-like organism test (also known as the Rapid Urease Test).

The duodenum is the most frequent site of small intestinal cancers [71]. The duodenum can be evaluated through the third portion with standard EGD, and can be evaluated in its entirety with push enteroscopy. However, push enteroscopy poses additional procedural time and therefore slightly increased risk, and its benefit in detection of early lesions remains unknown. Future studies should compare the effectiveness and burden of push enteroscopy versus standard upper endoscopy in Lynch syndrome. 


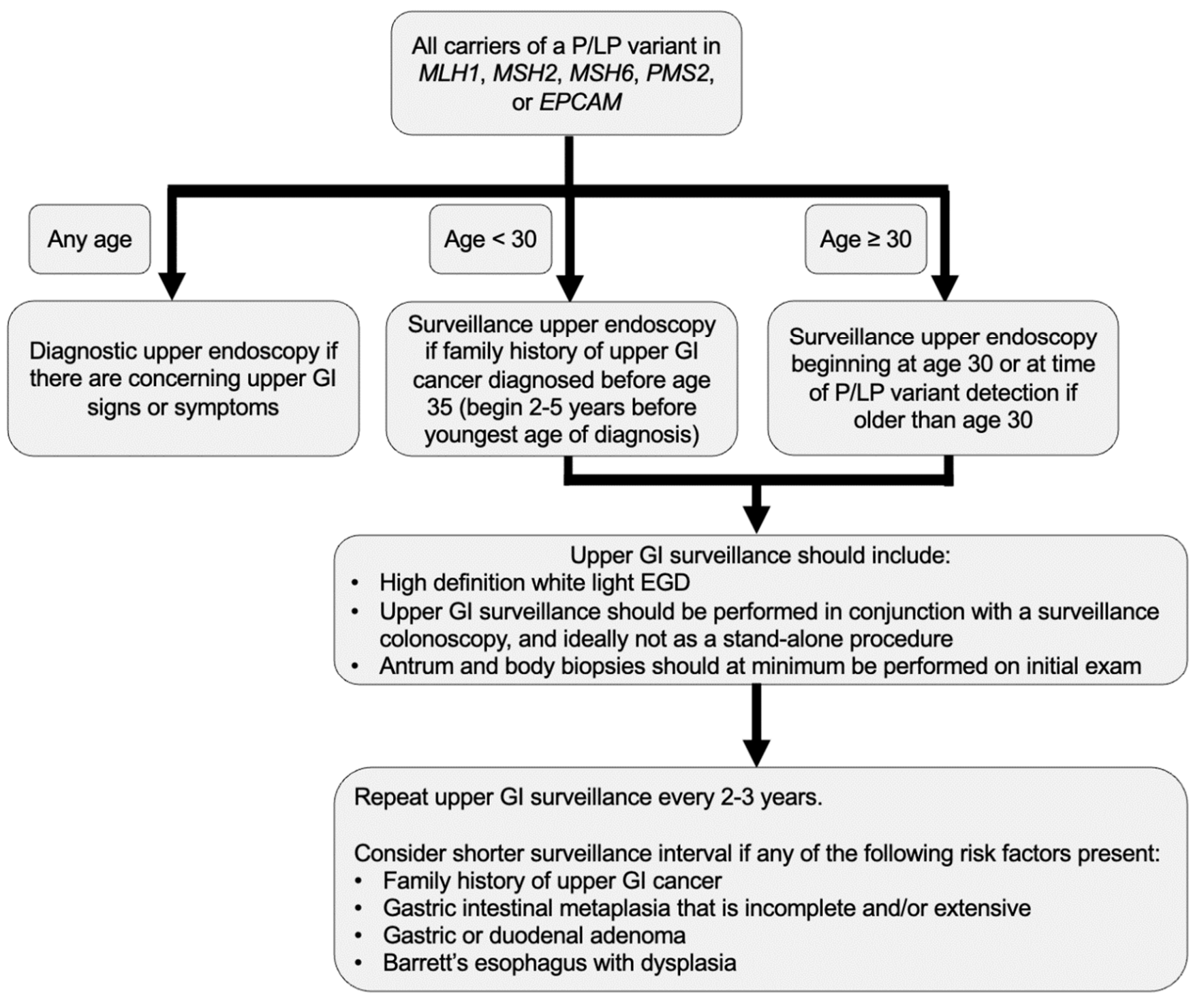

Figure 2. Authors' approach to Lynch syndrome upper GI cancer surveillance. P/LP variant: Pathogenic/Likely pathogenic variant; GI: Gastrointestinal; EGD: Esophagogastroduodenoscopy.

Overall, the topic of upper endoscopic surveillance in Lynch syndrome is not without its controversies, which include the age to initiate surveillance, the frequency of surveillance, and whether UGI surveillance should be targeted to certain Lynch syndrome sub-groups. Future studies will be needed to clarify these areas, particularly whether UGI surveillance is cost-effective and whether it prevents death from UGI cancer in Lynch syndrome. Large prospective consortium studies may be best suited to effectively answer these questions, given the relatively small numbers of single-center studies. An important consideration after consensus is reached regarding the need and methods of surveillance is whether there should be quality metrics regarding upper endoscopy for cancer detection in Lynch syndrome, akin to those in colonoscopy. This would ensure that upper endoscopy is of standardized quality across centers. 
Table 3. Studies evaluating surveillance of UGI cancer in Lynch syndrome.

\begin{tabular}{|c|c|c|c|c|c|c|c|}
\hline $\begin{array}{l}\text { Author } \\
\text { Year } \\
\text { Country }\end{array}$ & Study Design & & Pre-Cancerous Lesion Detection & & Cancers and Staging Detection & & Conclusions \\
\hline $\begin{array}{l}\text { Kumar [32] } \\
2020 \\
\text { United States }\end{array}$ & $\begin{array}{l}\text { Retrospective, Registry } \\
\text { Indication for EGD: symptoms } \\
\text { or surveillance } \\
\mathrm{N}=217\end{array}$ & $\begin{array}{l}\circ \\
\circ \\
\circ \\
\circ\end{array}$ & $\begin{array}{l}\text { BE: } 3.2 \% \\
\text { GIM: } 8.3 \% \\
\text { H pylori: } 2.8 \% \\
\text { Duodenal adenomas: } 1.8 \%\end{array}$ & $\begin{array}{l}\circ \\
\circ\end{array}$ & $\begin{array}{l}\text { UGI cancer: } 5 \%(11 / 217) \\
1 \text { esophageal squamous cell, } 6 \\
\text { gastric adenocarcinomas, } 4 \\
\text { duodenal adenocarcinomas } \\
5 / 11 \text { cancers detected on } \\
\text { surveillance, } 80 \% \text { stage I } \\
6 / 11 \text { detected on diagnostic EGD, } \\
33 \% \text { stage I }\end{array}$ & $\circ$ & $\begin{array}{l}\text { EGD surveillance associated with: } \\
\circ \quad \begin{array}{l}\text { Early-stage } \\
\text { cancer detection }\end{array}\end{array}$ \\
\hline $\begin{array}{l}\text { Farha [31] } \\
2021 \\
\text { United States }\end{array}$ & $\begin{array}{l}\text { Retrospective, Registry } \\
\text { Indication for EGD: } \\
\text { asymptomatic surveillance } \\
\mathrm{N}=323\end{array}$ & $\begin{array}{l}\circ \\
\circ \\
\circ \\
\circ \\
\circ\end{array}$ & $\begin{array}{l}\text { BE: } 6.5 \% \\
\text { H pylori: } 3.8 \% \\
\text { GIM: } 5.7 \% \\
\text { Gastric adenomas: } 0.6 \% \\
\text { Gastric hyperplastic } \\
\text { polyps > 5mm: } 1.9 \% \\
\text { Duodenal adenomas: } 1.5 \%\end{array}$ & $\begin{array}{l}\circ \\
\circ\end{array}$ & $\begin{array}{l}\text { UGI cancer: } 1.5 \%(5 / 323) \\
1 \text { esophageal adenocarcinoma, } \\
1 \text { gastric adenocarcinoma, } \\
1 \text { gastric NET, } \\
2 \text { duodenal adenocarcinomas } \\
4 / 5(80 \%) \text { detected at stage I and } \\
1 \text { patient at stage IIB }\end{array}$ & $\circ$ & 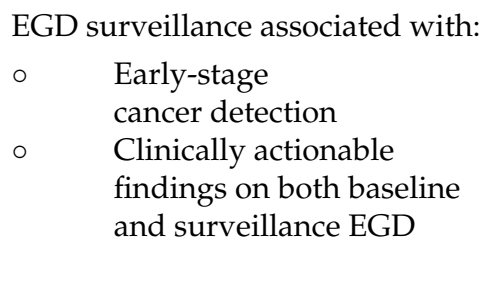 \\
\hline $\begin{array}{l}\text { Ceravolo [45] } \\
2021 \\
\text { United States }\end{array}$ & $\begin{array}{l}\text { Retrospective } \\
\text { Indication for EGD: } \\
\text { asymptomatic surveillance } \\
\mathrm{N}=247\end{array}$ & $\begin{array}{l}\circ \\
\circ \\
\circ \\
\circ \\
\circ\end{array}$ & $\begin{array}{l}\text { H pylori: } 6.9 \% \\
\text { GIM: } 10.1 \% \\
\text { Gastric adenoma: } 0.8 \% \\
\text { Duodenal adenoma: } 2.8 \% \\
\text { Ampullary adenoma: } 0.8 \%\end{array}$ & $\circ$ & $\begin{array}{l}\text { Gastric cancer: } 0.8 \%(2 / 247) \text {; one } \\
\text { stage pT1a and one stage pT3 } \\
\text { Duodenal cancer: } 0.8 \%(2 / 247) \text {, } \\
\text { one stage pT2 and one stage T1 }\end{array}$ & $\circ$ & $\begin{array}{l}\text { EGD surveillance is useful to: } \\
\circ \quad \begin{array}{l}\text { Detect precancerous and } \\
\text { cancerous UGI lesions }\end{array}\end{array}$ \\
\hline $\begin{array}{l}\text { Vangala }[65] \\
2021 \\
\text { Germany }\end{array}$ & $\begin{array}{l}\text { Retrospective, Registry } \\
\text { Indication for EGD: symptoms } \\
\text { or surveillance } \\
\mathrm{N}=2015\end{array}$ & $\circ$ & None described & $\circ$ & $\begin{array}{l}\text { Duodenal cancers in surveillance } \\
\text { group: } 13 / 27(48.1 \%) ; 77 \% \text { early } \\
\text { stage (I-IIA) } \\
\text { Duodenal cancers in diagnostic } \\
\text { group: } 14 / 27(51.9 \%) ; 29 \% \text { early } \\
\text { stage (I-IIA) }\end{array}$ & $\circ$ & $\begin{array}{l}\text { EGD surveillance associated with: } \\
\circ \quad \begin{array}{l}\text { Early detection of } \\
\text { duodenal cancers }\end{array}\end{array}$ \\
\hline
\end{tabular}


Table 3. Cont.

\begin{tabular}{|c|c|c|c|c|c|c|c|}
\hline $\begin{array}{l}\text { Author } \\
\text { Year } \\
\text { Country }\end{array}$ & Study Design & & Pre-Cancerous Lesion Detection & & Cancers and Staging Detection & & Conclusions \\
\hline $\begin{array}{l}\text { Galiatsatos [72] } \\
2017 \\
\text { Turkey }\end{array}$ & $\begin{array}{l}\text { Retrospective } \\
\text { Indication for EGD: not specified } \\
\mathrm{N}=21\end{array}$ & $\begin{array}{l}0 \\
0 \\
0\end{array}$ & $\begin{array}{l}\text { H pylori: } 9.5 \% \\
\text { Atrophic gastritis: } 0 \% \\
\text { GIM: } 9.5 \%\end{array}$ & $\circ$ & No cancers identified & $\circ$ & $\begin{array}{l}\text { EGD surveillance not } \\
\text { associated with: } \\
\begin{array}{l}\text { Detection of upper } \\
\text { gastrointestinal cancers }\end{array}\end{array}$ \\
\hline $\begin{array}{l}\text { Renkonen- } \\
\text { Sinisalo [73] } \\
2002 \\
\text { Finland }\end{array}$ & $\begin{array}{l}\text { Prospective one-time EGD, case-control } \\
\text { study including gastric biopsy } \\
N=73 \text { with Lynch syndrome and } \\
32 \text { mutation-negative family members }\end{array}$ & $\begin{array}{l}\circ \\
\circ \\
\circ \\
\circ\end{array}$ & $\begin{array}{l}\text { Case/Control } \\
\text { H pylori: } 26 / 28 \% \\
\text { Atrophic gastritis: } 14 / 22 \% \\
\text { GIM: } 14 / 19 \%\end{array}$ & $\circ$ & Duodenal cancer: $1.4 \%(1 / 105)$ & $\circ$ & $\begin{array}{l}\text { EGD surveillance not } \\
\text { associated with: } \\
\begin{array}{l}\text { Detection of early } \\
\text { stage cancer }\end{array} \\
\circ \quad \begin{array}{l}\text { Detection of } \\
\text { premalignant lesions }\end{array}\end{array}$ \\
\hline $\begin{array}{l}\text { Ladigan-Badura } \\
\text { S [46] } \\
2021 \\
\text { Germany }\end{array}$ & $\begin{array}{l}\text { Review of gastric cancer cases in the } \\
\text { German Consortium for Familial } \\
\text { Intestinal Cancer Registry } \\
\text { Indication for EGD: symptoms } \\
\text { or surveillance } \\
\mathrm{N}=1128\end{array}$ & $\circ$ & None described & $\begin{array}{l}\circ \\
\circ\end{array}$ & $\begin{array}{l}\text { Gastric cancer: } 2.3 \%(47 / 2009) \\
6 / 22 \text { patients had cancer detected } \\
\text { on surveillance; } 83 \% \text { Stage I } \\
16 / 22 \text { patients with no } \\
\text { surveillance had cancer } \\
\text { diagnosed; } 25 \% \text { Stage I }\end{array}$ & $\circ$ & $\begin{array}{l}\text { Surveillance EGD associated with: } \\
\circ \quad \begin{array}{l}\text { Early-stage } \\
\text { cancer detection }\end{array}\end{array}$ \\
\hline $\begin{array}{l}\text { Hammoudi [62] } \\
2019 \\
\text { France }\end{array}$ & $\begin{array}{l}\text { Retrospective, Assessment of duodenal } \\
\text { neoplasia on EGD or push EGD } \\
\text { Indication for EGD: not specified } \\
\mathrm{N}=154\end{array}$ & $\circ$ & Duodenal adenomas: $1.9 \%$ & $\begin{array}{l}0 \\
\circ\end{array}$ & $\begin{array}{l}\text { Duodenal cancer: } 2.6 \%(4 / 154) \\
75 \% \text { of patients with duodenal } \\
\text { cancer diagnosed at } \\
\text { advanced stage }\end{array}$ & $\circ$ & $\begin{array}{l}\text { Surveillance EGD associated with: } \\
\circ \quad \begin{array}{l}\text { Detection of pre-cancerous } \\
\text { and cancerous } \\
\text { duodenal lesions }\end{array}\end{array}$ \\
\hline
\end{tabular}

BE: Barrett's esophagus; GIM: gastric intestinal metaplasia; NET: neuroendocrine tumor; EGD: Esophagogastroduodenoscopy. 


\section{Limitations of the Lynch Syndrome UGI Surveillance Literature}

It is important to note that the existing Lynch syndrome UGI surveillance literature does have weaknesses, which are important to consider when interpreting the data. First, all of the published studies in this area were performed in a retrospective manner, and therefore may have been subject to bias, including selection bias. Furthermore, the published studies do not assess the impact of UGI surveillance on preventing death from UGI cancers, which is arguably the most important endpoint. A randomized controlled trial of UGI surveillance in Lynch syndrome would be the best method to obtain unbiased data about the efficacy of UGI surveillance in Lynch syndrome; however, it is unlikely that such a trial will ever be performed as currently it would be impractical to randomize individuals with Lynch syndrome to a no-surveillance arm. Instead, large prospective consortium studies of UGI surveillance in Lynch syndrome are likely going to be most effective at generating better data on upper GI surveillance in Lynch syndrome. Another major limitation of this literature is the lack of geographic and racial/ethnic diversity present in the published studies, which have primarily come from Europe and large academic centers in the United States. The outcomes of upper GI surveillance in Lynch syndrome amongst different populations remain unknown, and this certainly also merits further investigation.

\section{Conclusions}

Guidelines regarding surveillance for UGI cancers in Lynch syndrome remain an obfuscated area, posing a source of confusion to patients and providers alike. Recent studies have demonstrated the efficacy of endoscopic surveillance in detecting UGI cancers in patients at an early stage compared to those presenting for diagnostic upper endoscopy due to symptoms. Upper endoscopy is a safe and low burden procedure when coupled with colonoscopy, and while specific questions in this field require continued study, the emerging evidence suggests surveillance for UGI neoplasia in Lynch syndrome is warranted and should be considered as part of a Lynch syndrome cancer risk management plan.

Author Contributions: S.K.: study concept and design; drafting of the manuscript; critical revision of the manuscript for important intellectual content. N.F., C.A.B.: drafting of the manuscript; critical revision of the manuscript for important intellectual content. B.W.K.: study concept and design; drafting of the manuscript; critical revision of the manuscript for important intellectual content; study supervision. All authors have read and agreed to the published version of the manuscript.

Funding: This research and the article processing charge was supported by the Jason and Julie Borrelli Lynch Syndrome Research Fund.

Conflicts of Interest: The authors declare no conflict of interest.

\section{References}

1. Lynch, H.T.; Snyder, C.L.; Shaw, T.G.; Heinen, C.D.; Hitchins, M.P. Milestones of Lynch syndrome: 1895-2015. Nat. Rev. Cancer 2015, 15, 181-194. [CrossRef]

2. Bansidhar, B.J. Extracolonic manifestations of lynch syndrome. Clin. Colon. Rectal Surg. 2012, 25, 103-110. [CrossRef] [PubMed]

3. Velho, S.; Fernandes, M.S.; Leite, M.; Figueiredo, C.; Seruca, R. Causes and consequences of microsatellite instability in gastric carcinogenesis. World J. Gastroenterol. 2014, 20, 16433-16442. [CrossRef] [PubMed]

4. Wolf, A.I.; Buchanan, A.H.; Farkas, L.M. Historical review of Lynch syndrome. J. Coloproctol. 2013, 33, 95-110. [CrossRef]

5. Bansidhar, B.J.; Silinsky, J. History and pathogenesis of lynch syndrome. Clin. Colon. Rectal Surg. 2012, 25, 63-66. [CrossRef]

6. De Jong, A.E.; Morreau, H.; Van Puijenbroek, M.; Eilers, P.H.; Wijnen, J.; Nagengast, F.M.; Griffioen, G.; Cats, A.; Menko, F.H.; Kleibeuker, J.H.; et al. The role of mismatch repair gene defects in the development of adenomas in patients with HNPCC. Gastroenterology 2004, 126, 42-48. [CrossRef]

7. Weiss, J.M.; Gupta, S.; Burke, C.A.; Axell, L.; Chen, L.M.; Chung, D.C.; Clayback, K.M.; Dallas, S.; Felder, S.; Gbolahan, O.; et al.

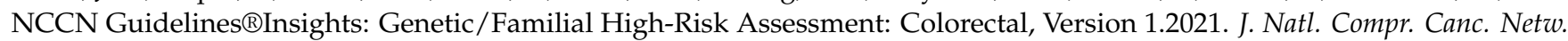
2021, 19, 1122-1132.

8. Bercow, A.S.; Eisenhauer, E.L. Screening and surgical prophylaxis for hereditary cancer syndromes with high risk of endometrial and ovarian cancer. J. Surg. Oncol. 2019, 120, 864-872. [CrossRef]

9. Cheng, L.; Eng, C.; Nieman, L.Z.; Kapadia, A.S.; Du, X.L. Trends in colorectal cancer incidence by anatomic site and disease stage in the United States from 1976 to 2005. Am. J. Clin. Oncol. 2011, 34, 573-580. [CrossRef] 
10. Bailey, C.E.; Hu, C.Y.; You, Y.N.; Bednarski, B.K.; Rodriguez-Bigas, M.A.; Skibber, J.M.; Cantor, S.B.; Chang, G.J. Increasing disparities in the age-related incidences of colon and rectal cancers in the United States, 1975-2010. JAMA Surg. 2015, 150, 17-22. [CrossRef]

11. Hamilton, S.R.; Liu, B.; Parsons, R.E.; Papadopoulos, N.; Jen, J.; Powell, S.M.; Krush, A.J.; Berk, T.; Cohen, Z.; Tetu, B.; et al. The molecular basis of Turcot's syndrome. N. Engl. J. Med. 1995, 332, 839-847. [CrossRef] [PubMed]

12. Siegel, R.L.; Miller, K.D.; Jemal, A. Cancer statistics, 2019. CA Cancer J. Clin. 2019, 69, 7-34. [CrossRef] [PubMed]

13. Dominguez-Valentin, M.; Sampson, J.R.; Seppala, T.T.; Ten Broeke, S.W.; Plazzer, J.P.; Nakken, S.; Engel, C.; Aretz, S.; Jenkins, M.A.; Sunde, L.; et al. Cancer risks by gene, age, and gender in 6350 carriers of pathogenic mismatch repair variants: Findings from the Prospective Lynch Syndrome Database. Genet. Med. 2020, 22, 15-25. [CrossRef] [PubMed]

14. Monahan, K.J.; Bradshaw, N.; Dolwani, S.; Desouza, B.; Dunlop, M.G.; East, J.E.; Ilyas, M.; Kaur, A.; Lalloo, F.; Latchford, A.; et al. Guidelines for the management of hereditary colorectal cancer from the British Society of Gastroenterology (BSG)/Association of Coloproctology of Great Britain and Ireland (ACPGBI)/United Kingdom Cancer Genetics Group (UKCGG). Gut 2020, 69, 411-444. [CrossRef]

15. Stoffel, E.M.; Mangu, P.B.; Gruber, S.B.; Hamilton, S.R.; Kalady, M.F.; Lau, M.W.; Lu, K.H.; Roach, N.; Limburg, P.J.; American Society of Clinical; et al. Hereditary colorectal cancer syndromes: American Society of Clinical Oncology Clinical Practice Guideline endorsement of the familial risk-colorectal cancer: European Society for Medical Oncology Clinical Practice Guidelines. J. Clin. Oncol. 2015, 33, 209-217. [CrossRef] [PubMed]

16. Balmana, J.; Balaguer, F.; Cervantes, A.; Arnold, D.; Group, E.G.W. Familial risk-colorectal cancer: ESMO Clinical Practice Guidelines. Ann. Oncol. 2013, 24 (Suppl. S6), vi73-vi80. [CrossRef] [PubMed]

17. Giardiello, F.M.; Allen, J.I.; Axilbund, J.E.; Boland, C.R.; Burke, C.A.; Burt, R.W.; Church, J.M.; Dominitz, J.A.; Johnson, D.A.; Kaltenbach, T.; et al. Guidelines on genetic evaluation and management of Lynch syndrome: A consensus statement by the US Multi-Society Task Force on colorectal cancer. Gastroenterology 2014, 147, 502-526. [CrossRef] [PubMed]

18. Syngal, S.; Brand, R.E.; Church, J.M.; Giardiello, F.M.; Hampel, H.L.; Burt, R.W.; American College of Gastroenterology. ACG clinical guideline: Genetic testing and management of hereditary gastrointestinal cancer syndromes. Am. J. Gastroenterol. 2015, 110, 223-262. [CrossRef]

19. Vangala, D.B.; Cauchin, E.; Balmana, J.; Wyrwicz, L.; van Cutsem, E.; Guller, U.; Castells, A.; Carneiro, F.; Hammel, P.; Ducreux, M.; et al. Screening and surveillance in hereditary gastrointestinal cancers: Recommendations from the European Society of Digestive Oncology (ESDO) expert discussion at the 20th European Society for Medical Oncology (ESMO)/World Congress on Gastrointestinal Cancer, Barcelona, June 2018. Eur. J. Cancer 2018, 104, 91-103. [CrossRef]

20. Huneburg, R.; Aretz, S.; Buttner, R.; Daum, S.; Engel, C.; Fechner, G.; Habermann, J.K.; Heling, D.; Hoffmann, K.; Holinski-Feder, E.; et al. Current recommendations for surveillance, risk reduction and therapy in Lynch syndrome patients. Z. Gastroenterol. 2019, 57, 1309-1320. [CrossRef]

21. Seppala, T.T.; Latchford, A.; Negoi, I.; Sampaio Soares, A.; Jimenez-Rodriguez, R.; Sanchez-Guillen, L.; Evans, D.G.; Ryan, N.; Crosbie, E.J.; Dominguez-Valentin, M.; et al. European guidelines from the EHTG and ESCP for Lynch syndrome: An updated third edition of the Mallorca guidelines based on gene and gender. Br. J. Surg. 2021, 108, 484-498. [CrossRef] [PubMed]

22. Short, M.W.; Burgers, K.G.; Fry, V.T. Esophageal Cancer. Am. Fam. Physician 2017, 95, 22-28. [PubMed]

23. Dubecz, A.; Solymosi, N.; Stadlhuber, R.J.; Schweigert, M.; Stein, H.J.; Peters, J.H. Does the Incidence of Adenocarcinoma of the Esophagus and Gastric Cardia Continue to Rise in the Twenty-First Century?-A SEER Database Analysis. J. Gastrointest. Surg. 2013, 18, 124-129. [CrossRef] [PubMed]

24. Codipilly, D.C.; Sawas, T.; Dhaliwal, L.; Johnson, M.L.; Lansing, R.; Wang, K.K.; Leggett, C.L.; Katzka, D.A.; Iyer, P.G. Epidemiology and Outcomes of Young-Onset Esophageal Adenocarcinoma: An Analysis from a Population-Based Database. Cancer Epidemiol. Biomark. Prev. 2020, 30, 142-149. [CrossRef]

25. Spataro, J.; Zfass, A.M.; Schubert, M.; Shah, T. Early Esophageal Cancer: A Gastroenterologist's Disease. Dig. Dis. Sci. 2019, 64, 3048-3058. [CrossRef]

26. Committee, A.T.; Thosani, N.; Abu Dayyeh, B.K.; Sharma, P.; Aslanian, H.R.; Enestvedt, B.K.; Komanduri, S.; Manfredi, M.; Navaneethan, U.; Maple, J.T.; et al. ASGE Technology Committee systematic review and meta-analysis assessing the ASGE Preservation and Incorporation of Valuable Endoscopic Innovations thresholds for adopting real-time imaging-assisted endoscopic targeted biopsy during endoscopic surveillance of Barrett's esophagus. Gastrointest. Endosc. 2016, 83, 684-698.e7. [CrossRef]

27. Cerrone, S.A.; Trindade, A.J. Advanced imaging in surveillance of Barrett's esophagus: Is the juice worth the squeeze? World J. Gastroenterol. 2019, 25, 3108-3115. [CrossRef]

28. Everson, M.A.; Ragunath, K.; Bhandari, P.; Lovat, L.; Haidry, R. How to Perform a High-Quality Examination in Patients with Barrett's Esophagus. Gastroenterology 2018, 154, 1222-1226. [CrossRef]

29. Levine, D.S.; Blount, P.L.; Rudolph, R.E.; Reid, B.J. Safety of a systematic endoscopic biopsy protocol in patients with Barrett's esophagus. Am. J. Gastroenterol. 2000, 95, 1152-1157. [CrossRef]

30. Asge Standards of Practice Committee; Qumseya, B.; Sultan, S.; Bain, P.; Jamil, L.; Jacobson, B.; Anandasabapathy, S.; Agrawal, D.; Buxbaum, J.L.; Fishman, D.S.; et al. ASGE guideline on screening and surveillance of Barrett's esophagus. Gastrointest. Endosc. 2019, 90, 335-359.e2. [CrossRef] 
31. Farha, N.; Hrabe, J.; Sleiman, J.; Beard, J.; Lyu, R.; Bhatt, A.; Church, J.; Heald, B.; Liska, D.; Mankaney, G.; et al. Clinically actionable findings on surveillance EGD in asymptomatic patients with Lynch syndrome. Gastrointest. Endosc. 2021, 95, 105-114. [CrossRef] [PubMed]

32. Kumar, S.; Dudzik, C.M.; Reed, M.; Long, J.M.; Wangensteen, K.J.; Katona, B.W. Upper Endoscopic Surveillance in Lynch Syndrome Detects Gastric and Duodenal Adenocarcinomas. Cancer Prev. Res. 2020, 13, 1047-1054. [CrossRef] [PubMed]

33. Ronkainen, J.; Aro, P.; Storskrubb, T.; Johansson, S.E.; Lind, T.; Bolling-Sternevald, E.; Vieth, M.; Stolte, M.; Talley, N.J.; Agreus, L. Prevalence of Barrett's esophagus in the general population: An endoscopic study. Gastroenterology 2005, 129, $1825-1831$. [CrossRef] [PubMed]

34. Cameron, A.J.; Lomboy, C.T. Barrett's esophagus: Age, prevalence, and extent of columnar epithelium. Gastroenterology 1992, 103, 1241-1245. [CrossRef]

35. Hayeck, T.J.; Kong, C.Y.; Spechler, S.J.; Gazelle, G.S.; Hur, C. The prevalence of Barrett's esophagus in the US: Estimates from a simulation model confirmed by SEER data. Dis. Esophagus 2010, 23, 451-457. [CrossRef]

36. Farha, N.; Savage, E.; Sleiman, J.; Burke, C.A. Using Immunohistochemistry to Expand the Spectrum of Lynch Syndrome-Related Tumors. ACG Case Rep. J. 2021, 8, e00691. [CrossRef]

37. Sasaki, H.; Yamashita, K.; Nakase, H. Pedunculated Upper Esophageal Adenocarcinoma in Lynch Syndrome. Clin. Gastroenterol. Hepatol. 2019, 17, A20. [CrossRef]

38. Sweetser, S.; Chandan, V.S.; Baron, T.H. Dysphagia in Lynch syndrome. Gastroenterology 2013, 145, 1167-1168. [CrossRef]

39. Chong, V.H. Clinical significance of heterotopic gastric mucosal patch of the proximal esophagus. World J. Gastroenterol. 2013, 19, 331-338. [CrossRef]

40. Neumann, W.L.; Lujan, G.M.; Genta, R.M. Gastric heterotopia in the proximal oesophagus ("inlet patch"): Association with adenocarcinomas arising in Barrett mucosa. Dig. Liver Dis. 2012, 44, 292-296. [CrossRef]

41. Falkenback, D.; Johansson, J.; Halvarsson, B.; Nilbert, M. Defective mismatch-repair as a minor tumorigenic pathway in Barrett esophagus-associated adenocarcinoma. Cancer Genet. Cytogenet. 2005, 157, 82-86. [CrossRef]

42. Van Nistelrooij, A.M.; Dinjens, W.N.; Wagner, A.; Spaander, M.C.; van Lanschot, J.J.; Wijnhoven, B.P. Hereditary Factors in Esophageal Adenocarcinoma. Gastrointest. Tumors 2014, 1, 93-98. [CrossRef]

43. Mankaney, G.; Macaron, C.; Burke, C.A. Refining Risk Factors for Gastric Cancer in Patients with Lynch Syndrome to Optimize Surveillance Esophagogastroduodenoscopy. Clin. Gastroenterol. Hepatol. 2020, 18, 780-782. [CrossRef] [PubMed]

44. Kim, J.; Braun, D.; Ukaegbu, C.; Dhingra, T.G.; Kastrinos, F.; Parmigiani, G.; Syngal, S.; Yurgelun, M.B. Clinical Factors Associated with Gastric Cancer in Individuals with Lynch Syndrome. Clin. Gastroenterol. Hepatol. 2020, 18, 830-837.e1. [CrossRef] [PubMed]

45. Ceravolo, A.H.; Yang, J.J.; Latham, A.; Markowitz, A.J.; Shia, J.; Mermelstein, J.; Calo, D.; Gerdes, H.; Ludwig, E.; Schattner, M.A.; et al. Effectiveness of a surveillance program of upper endoscopy for upper gastrointestinal cancers in Lynch syndrome patients. Int. J. Colorectal Dis. 2021, 37, 231-238. [CrossRef] [PubMed]

46. Ladigan-Badura, S.; Vangala, D.B.; Engel, C.; Bucksch, K.; Hueneburg, R.; Perne, C.; Nattermann, J.; Steinke-Lange, V.; Rahner, N.; Schackert, H.K.; et al. Value of upper gastrointestinal endoscopy for gastric cancer surveillance in patients with Lynch syndrome. Int. J. Cancer 2021, 148, 106-114. [CrossRef]

47. Chautard, R.; Malka, D.; Samaha, E.; Tougeron, D.; Barbereau, D.; Caron, O.; Rahmi, G.; Barrioz, T.; Cellier, C.; Feau, S.; et al. Upper Gastrointestinal Lesions during Endoscopy Surveillance in Patients with Lynch Syndrome: A Multicentre Cohort Study. Cancers 2021, 13, 1657. [CrossRef]

48. Moller, P.; Seppala, T.T.; Bernstein, I.; Holinski-Feder, E.; Sala, P.; Gareth Evans, D.; Lindblom, A.; Macrae, F.; Blanco, I.; Sijmons, R.H.; et al. Cancer risk and survival in path_MMR carriers by gene and gender up to 75 years of age: A report from the Prospective Lynch Syndrome Database. Gut 2018, 67, 1306-1316. [CrossRef]

49. Capelle, L.G.; Van Grieken, N.C.; Lingsma, H.F.; Steyerberg, E.W.; Klokman, W.J.; Bruno, M.J.; Vasen, H.F.; Kuipers, E.J. Risk and epidemiological time trends of gastric cancer in Lynch syndrome carriers in the Netherlands. Gastroenterology 2010, 138, 487-492. [CrossRef]

50. Engel, C.; Loeffler, M.; Steinke, V.; Rahner, N.; Holinski-Feder, E.; Dietmaier, W.; Schackert, H.K.; Goergens, H.; von Knebel Doeberitz, M.; Goecke, T.O.; et al. Risks of less common cancers in proven mutation carriers with lynch syndrome. J. Clin. Oncol. 2012, 30, 4409-4415. [CrossRef]

51. Bonadona, V.; Bonaiti, B.; Olschwang, S.; Grandjouan, S.; Huiart, L.; Longy, M.; Guimbaud, R.; Buecher, B.; Bignon, Y.J.; Caron, O.; et al. Cancer risks associated with germline mutations in MLH1, MSH2, and MSH6 genes in Lynch syndrome. JAMA 2011, 305, 2304-2310. [CrossRef]

52. Correa, P.; Piazuelo, M.B. Helicobacter pylori Infection and Gastric Adenocarcinoma. US Gastroenterol. Hepatol. Rev. 2011, 7, $59-64$.

53. Crowe, S.E. Helicobacter pylori Infection. N. Engl. J. Med. 2019, 380, 1158-1165. [CrossRef]

54. Adar, T.; Friedman, M.; Rodgers, L.H.; Shannon, K.M.; Zukerberg, L.R.; Chung, D.C. Gastric cancer in Lynch syndrome is associated with underlying immune gastritis. J. Med. Genet. 2019, 56, 844-845. [CrossRef]

55. Soer, E.C.; Leicher, L.W.; Langers, A.M.; van de Meeberg, P.C.; van der Wouden, E.J.; Koornstra, J.J.; Bigirwamungu-Bargeman, M.; Vasen, H.F.; de Vos tot Nederveen Cappel, W.H. Equivalent Helicobacter pylori infection rates in Lynch syndrome mutation carriers with and without a first-degree relative with gastric cancer. Int. J. Colorectal Dis. 2016, 31, 693-697. [CrossRef] [PubMed] 
56. Vasen, H.F.; Blanco, I.; Aktan-Collan, K.; Gopie, J.P.; Alonso, A.; Aretz, S.; Bernstein, I.; Bertario, L.; Burn, J.; Capella, G.; et al. Revised guidelines for the clinical management of Lynch syndrome (HNPCC): Recommendations by a group of European experts. Gut 2013, 62, 812-823. [CrossRef] [PubMed]

57. Kumar, S.; Metz, D.C.; Ellenberg, S.; Kaplan, D.E.; Goldberg, D.S. Risk Factors and Incidence of Gastric Cancer After Detection of Helicobacter pylori Infection: A Large Cohort Study. Gastroenterology 2019, 158, 527-536.e7. [CrossRef] [PubMed]

58. Lynch, H.T.; Smyrk, T.; Jass, J.R. Hereditary nonpolyposis colorectal cancer and colonic adenomas: Aggressive adenomas? Semin. Surg. Oncol. 1995, 11, 406-410. [CrossRef]

59. Ladigan, S.; Vangala, D.B.; Kuhlkamp, J.; Pox, C.; Engel, C.; Hueneburg, R.; Perne, C.; Nattermann, J.; Steinke-Lange, V.; Rahner, N.; et al. Value of EGD for gastric cancer surveillance in patients with hereditary non-polyposis colorectal cancer (HNPCC) or Lynch syndrome (LS). J. Clin. Oncol. 2018, 36, 1522. [CrossRef]

60. Schulmann, K.; Brasch, F.E.; Kunstmann, E.; Engel, C.; Pagenstecher, C.; Vogelsang, H.; Kruger, S.; Vogel, T.; Knaebel, H.P.; Ruschoff, J.; et al. HNPCC-associated small bowel cancer: Clinical and molecular characteristics. Gastroenterology 2005, 128, 590-599. [CrossRef]

61. Shenoy, S. Genetic risks and familial associations of small bowel carcinoma. World J. Gastrointest. Oncol. 2016, 8, 509-519. [CrossRef]

62. Hammoudi, N.; Dhooge, M.; Coriat, R.; Leblanc, S.; Barret, M.; Bordacahar, B.; Beuvon, F.; Prat, F.; Maksimovic, F.; Chaussade, S. Duodenal tumor risk in Lynch syndrome. Dig. Liver Dis. 2019, 51, 299-303. [CrossRef]

63. Kidambi, T.D.; Pedley, C.; Blanco, A.; Bergsland, E.K.; Terdiman, J.P. Lower gastrointestinal neuroendocrine neoplasms associated with hereditary cancer syndromes: A case series. Fam. Cancer 2017, 16, 537-543. [CrossRef]

64. Rodriguez-Bigas, M.A.; Vasen, H.F.; Lynch, H.T.; Watson, P.; Myrhoj, T.; Jarvinen, H.J.; Mecklin, J.P.; Macrae, F.; St John, D.J.; Bertario, L.; et al. Characteristics of small bowel carcinoma in hereditary nonpolyposis colorectal carcinoma. International Collaborative Group on HNPCC. Cancer 1998, 83, 240-244. [CrossRef]

65. Vangala, D.B.; Ladigan-Badura, S.; Engel, C.; Huneburg, R.; Perne, C.; Bucksch, K.; Nattermann, J.; Steinke-Lange, V.; Rahner, N.; Weitz, J.; et al. Early detection of duodenal cancer by upper gastrointestinal-endoscopy in Lynch syndrome. Int. J. Cancer 2021, 149, 2052-2062. [CrossRef] [PubMed]

66. Wu, A.H.; Yu, M.C.; Mack, T.M. Smoking, alcohol use, dietary factors and risk of small intestinal adenocarcinoma. Int. J. Cancer 1997, 70, 512-517. [CrossRef]

67. Kaerlev, L.; Teglbjaerg, P.S.; Sabroe, S.; Kolstad, H.A.; Ahrens, W.; Eriksson, M.; Guenel, P.; Hardell, L.; Launoy, G.; Merler, E.; et al. Is there an association between alcohol intake or smoking and small bowel adenocarcinoma? Results from a European multi-center case-control study. Cancer Causes Control 2000, 11, 791-797. [CrossRef] [PubMed]

68. Richter, J.M.; Kelsey, P.B.; Campbell, E.J. Adverse Event and Complication Management in Gastrointestinal Endoscopy. Am. J. Gastroenterol. 2016, 111, 348-352. [CrossRef]

69. Levy, I.; Gralnek, I.M. Complications of diagnostic colonoscopy, upper endoscopy, and enteroscopy. Best Pract. Res. Clin. Gastroenterol. 2016, 30, 705-718. [CrossRef]

70. Ahadova, A.; Seppala, T.T.; Engel, C.; Gallon, R.; Burn, J.; Holinski-Feder, E.; Steinke-Lange, V.; Moslein, G.; Nielsen, M.; Ten Broeke, S.W.; et al. The "unnatural" history of colorectal cancer in Lynch syndrome: Lessons from colonoscopy surveillance. Int. J. Cancer 2021, 148, 800-811. [CrossRef]

71. Haanstra, J.F.; Al-Toma, A.; Dekker, E.; Vanhoutvin, S.A.; Nagengast, F.M.; Mathus-Vliegen, E.M.; van Leerdam, M.E.; de Vos tot Nederveen Cappel, W.H.; Sanduleanu, S.; Veenendaal, R.A.; et al. Prevalence of small-bowel neoplasia in Lynch syndrome assessed by video capsule endoscopy. Gut 2015, 64, 1578-1583. [CrossRef] [PubMed]

72. Galiatsatos, P.; Labos, C.; Jeanjean, M.; Miller, K.; Foulkes, W.D. Low yield of gastroscopy in patients with Lynch syndrome. Turk. J. Gastroenterol. 2017, 28, 434-438. [CrossRef] [PubMed]

73. Renkonen-Sinisalo, L.; Sipponen, P.; Aarnio, M.; Julkunen, R.; Aaltonen, L.A.; Sarna, S.; Jarvinen, H.J.; Mecklin, J.P. No support for endoscopic surveillance for gastric cancer in hereditary non-polyposis colorectal cancer. Scand. J. Gastroenterol. 2002, 37, 574-577. [CrossRef] [PubMed] 